\title{
EMPLOYEE TURNOVER AND OPERATIONAL PERFORMANCE OF COMMERCIAL BANKS IN RWANDA
}

\author{
Ephrem KAYUMBA ${ }^{1 *}$, CLAUDE RUSIBANA ${ }^{2}$ \\ *l Mount Kenya University Rwanda,${ }^{2}$ University of Kigali
}

*Corresponding Author: -

\begin{abstract}
: -
Employee turnover was the movement through which an organization hired and missed its employees. This might be voluntary, involuntary, internal transfer, and retirement turnover. The objective of this study was to analyse the employee turnover and operational performance of commercial banks in Rwanda, a case of KCB Bank Rwanda located in Nyarugenge District, Rwanda. The specific objectives were to analyse the effect of employee compensation on operational performance, to determine the impact of employee overscheduling on operational performance, and to find out the impact of employee favouritism on the operational performance of KCB Bank Rwanda. This quantitative research used the descriptive research survey design with questionnaire as research instrument where 80 questionnaires were distributed to 80 employees by using both physical and digital approaches forms due to situations of COVID-19. The data collection took six months and consisted of 15 Microsoft forms, 40 physical forms, and 25 emails responses. The data analysis was done by using Statistical Package for Social Science (SPSS) version 20 through which the census method was applied, and the descriptive method was used to make the conclusion and has been applied to determine the reliability and validity at 0.8\%. This research contributed to the management of employee turnover to improve operational performance of commercial banks in Rwanda. It indicated that KCB Bank Rwanda recognized a considerable rate of employee turnover at a percentage of $46.5 \%$ since its creation in 2008 year to December 2020 where the low number of recruited employees compared to the number of employees who exited. This was caused by factors including poor employee compensation, employee overscheduling and employee favouritism. The study discovered that the research objectives were major causes of employee turnover that affected the operational performance of KCB Bank Rwanda at a percentage of 13.8\%. Data analysis showed that compensation affected the bank's operations at a percentage of $73.8 \%$ (see table 4.9.), overscheduling at $50.1 \%$ (see table 4.7), and favouritism at $56.3 \%$ (see table 4.8). The study discovered that the most concern of KCB Bank Rwanda was not the relevance of number of employees who left but the quality of those employee and the targets they had set during the set and submission of the annual balanced scorecard, which affects the operational performance review. The research recommended that the management should review the compensation policy to match the operational performance, reduce favouritism by approaching marginal employees, and reduce overscheduling by re-examining the job descriptions and visiting employee's office to discover added and non-corresponding duties that attracted the employee turnover in the KCB Bank Rwanda.
\end{abstract}

Keywords: Balanced Scorecard, operational performance, employee Turnover.

\section{(a) $(\$)$}




\section{INTRODUCTION}

The role of employment has remained considerable in advancing the socio-economic and socio-political development of Rwanda but many job opportunities were generated traditionally, and their evolution was advanced than in modern employment. According to Mrope (2014), employee turnover was a serious threat to the growth of commercial institutions. According to Silas (2015), commercial banking system in Rwanda was composed by sixteen commercial banks including Investment and Mortgages Bank Rwanda, Guarantee Trust Bank Rwanda, KCB Bank Rwanda, Urwego Opportunity Bank, Zigama Credit and Savings Bank, Compagnie Générale des Banques, Access Bank Rwanda, Bank of Kigali, Arab and Bangladesh Bank, Bank of Africa, National Credit Bank of Africa, Equity bank Rwanda, Banque Populaire du Rwanda, Ecobank Rwanda, Unguka Bank, and Development Bank of Rwanda (Silas, 2015)

According to National Bank of Rwanda (2018-2019), KCB Bank Rwanda lacked mitigating strategies to retain its trained and experienced employees which delayed its operational performance including the delay in clearing and payment of cheques, time wasted in bank hall as customers lined waiting for service, errors, and fraud related cases (BNR, 2019). According to field data (2020), the problem of the exit of experienced employees affected the business volumes of KCB Bank Rwanda whereas about $68.8 \%$ employees had intendancy to exit the bank in nearby future while the $23.0 \%$ employees were not sure if they could remain due to heavy tasks overscheduled to them. The operational performance was affected at $1.3 \%$ and this caused the $50.1 \%$ employee to lose their happiness. The bank's quality of service remained below expectation driving the bank to a poor performance that weakened its operational performance weigh heavily where $56.3 \%$ employee intended to exit the bank due to favouritism.

Compensation system had inequality and led to the intent of employees to exit at a percentage of $67.6 \%$. the bank suffered from employee turnover through which the unit of facilities and procurement and the department of human resource management left empty consecutively during 2018-2020 years. KCB Bank Rwanda has been weakened by the effectiveness of its operational performance and the challenges of low compliance culture, customer dissatisfaction and complaints, followed by resignations of experienced and competent employees, (IMF, 2011). Thus, the bank's management overscheduled duties over employees in order to cover the gap while waiting to attract and recruit new employees that has put the bank at a risk of losing qualified employees at a percentage of $37.5 \%$.

According to Herbert (2013), descriptive way has enabled the scholar to collect, present and interpret the data. The assortment process through questionnaire in order to answer questions amongst carefully chosen people. During the data analysis, the Numerical Compendium for Public Studentship (SPSS) software version 20 has been applied in the data analysis process. This descriptive method helped the researcher in making the decision and it used the percentage of 98\% as confidence level (Herbert, 2013). According to Carole (2018), sampling design has been comprised of the strategy related to sampling techniques. In this study, census method was applied where all population were considered as model proportions.

$$
\left(\mathbf{n}=\frac{N}{1+N(\mathrm{e})^{2}}\right)
$$

Throughout the interpretation of the formula, "n" symbolized the sample size, "N" stood for the population size of 400 employees, and "e" meant 0.01 as the level of precision and/or margin error. Therefore, the sample size was calculated per below:

$$
\begin{gathered}
\left(\mathbf{n}=\frac{400}{1+400(0.1)^{2}}\right)=\frac{400}{(0.01 \times 400)+1} \\
=\frac{400}{4+1}=\frac{400}{5}=80
\end{gathered}
$$

Thus, the sample size was 80 employees of KCB Bank Rwanda. According to Edward (2014), the targeted population came from the objectives of this study which argument the individual or group of people in compliance to the research standard. According to KCB Bank Rwanda's reporting benchmark (2019), the bank has 220 employees in Rwanda whereas the target population was 80 employees and thus, census method has been used to mitigate the research standard. Data collected were inputted into statistical packaging for social sciences (SPSS) software version 20, as a leading academic research analysis technique. This had been done through the application of descriptive statistics that inputted data from frequency to percentage of result, and this enabled the researcher to determine the relationship between two variables that were employee turnover and operational performance.

\footnotetext{
Research Objectives

i. To analyse the effect of employee compensation on operational performance of KCB Bank Rwanda.

ii. To determine the effect of employee over scheduling on operational performance of KCB Bank Rwanda.

iii. To find out the effect of employee favouritism on the operational performance of KCB Bank Rwanda.

iv. To evaluate the operational performance of KCB Bank Rwanda

v. To analyse the operational performance of KCB Bank Rwanda.
} 


\section{Research Questions}

i. Does employee compensation affect the operational performance of KCB Bank Rwanda?

ii. What is the effect of employee over scheduling on operational performance of KCB Bank Rwanda?

iii. How does favouritism of employee affect operational performance of KCB Bank Rwanda?

iv. What is the status of the operational performance of KCB Bank Rwanda?

v. How is the operational performance of KCB Bank Rwanda?

\section{Literature Review}

According to Wanderi (2012), compensation is the main cause when the employees are looking for the increase of their income. It is clear that an employee exits one job and go to start another occupation which pays more. The employees' compensation embraces commission and overtime, the tip income, the advantage and appreciation, and the benefits which include indemnifications, customary occupational program, and the retirement, the standard preferences, and any other paybacks which worker may advantage from the employer. According to Immaculée (2014), in dynamic and profit-making productions, capacity changes normally and chiefs understaffing of teams after graft mandate teams feeling high burden. employees calling in sick or not reporting for duty on time due to unforeseen traumas, super vision lacking to hire last-minute that high, arrangement by taking two main causes into excuse. This has put the pressure to the employees bringing to busy working environment which have created the conflicts between customers and organizations and this has increased employee turnover for commercial banks in Rwanda. (Immaculée, 2014). According to Carole (2018), employee favouritism in the workplace is defined as favouring an employee not because of realizing great job but for the reasons different from servant act. The form of favouritism is nepotism. From the Italian word for nephew, "nipote," acumen is show family cohorts. In a work situation, family members may be hired, promoted, or otherwise unfairly favoured over other candidates, simply because they're part of the family. Illustrations of partiality in the workplace are when two co-workers worked together previously and have a shared history or they have bonded over common outside interests, like sports or music. preferential treatment shop floor can convert worst when these rapports turn into would-be bother (Carole, 2018).

According to $\mathrm{Ng}$ 'ethe (2012), compensation, relationship between employee and management, career progression, quality leadership. The stratagem which can be make use of in employee gross revenue creation of contributing to work location for member of staff. Work background reasons that affect employee pronouncement visit union. According to Herzberg two factor theory is a dual styles of employee turnover which are the motivation and the satisfaction of employees in the organization. This theory convinces that those factors cause job satisfaction to the employees. In this context, the factors that originate employee consummation go with the aspects that cause dissatisfaction. This means that one factor increases as the factor decreases.

According to Adnan (2017), operational performance is an achievement of duties which is calculated through the identified by the compliance of standards, the achievement of targets which is linked to the cost incurred and the speed of turnaround time. Afshan said this while determining that the performance of institution proves an improvement in production, easiness in familiarizing to technology, and highly motivated workers.

\section{Conceptual Framework}

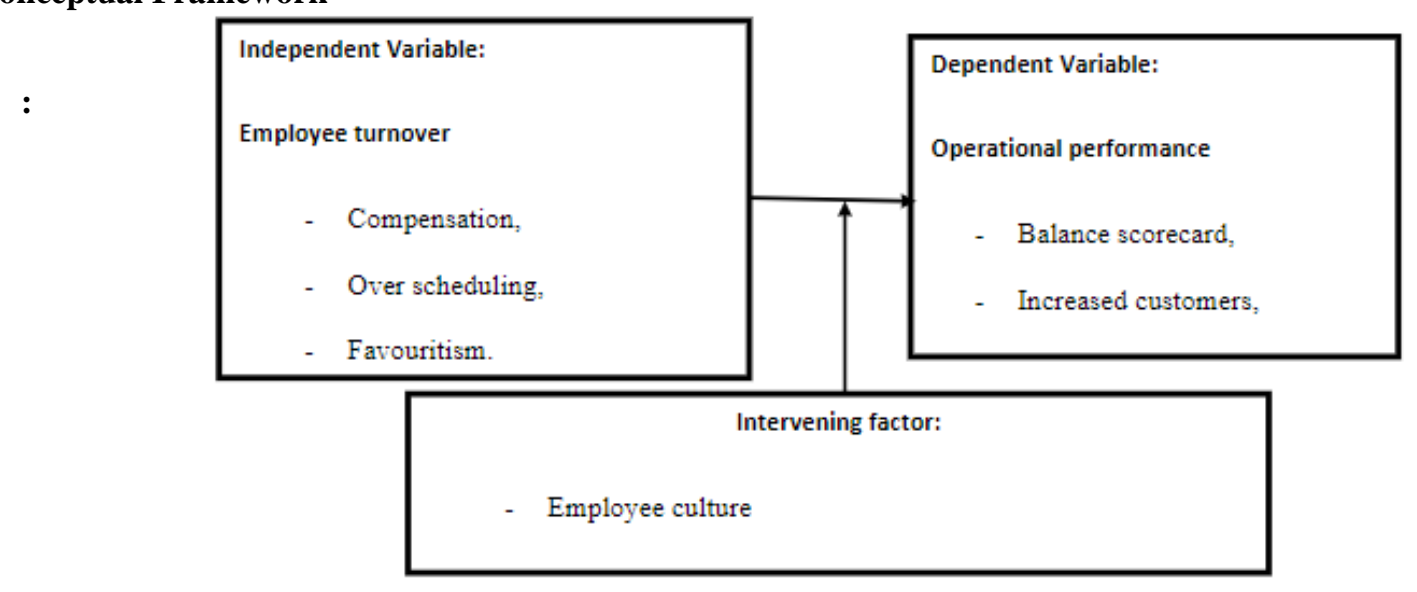

According to Herbert (2013), the lack of compensation causes the employee turnover in KCB Bank which affect its operational performance and bans the realization and the achievement of set targets as seen in the balanced scorecards (BSC). Compensation is a pay or reward which an employee receives arisen from occupation. According to Nuray, (2016). Compensation can be financial payments like wages, salaries, incentives, commissions, bonuses and/or coverages like insurance, transport etc. (Nuray, 2016).

According to Mahoney (2012), overscheduling means the too much organized activity participation upon employee which lead to the poor developmental outcomes. The increase of responsibilities cause employee to exit which affect the bank's strategy to recruit more customers over their extensive time commitment. Herein, customers are found lining and/or sitting down in the bank hall while they are waiting for services ahead the employee who also have other duties to accomplish with deadlines including daily reports, etc. Favouritism interdicted employees from realizing the 
innovation and this affected the operational performance. The employee culture intervenes because there are employees who can't live away from their families and who can't adopt on the fall night of close of business. This affect the operational performance of KCB Bank Rwanda through its strategy of duty rotation practiced with the aim to achieve the bank's annual targets (Mahoney, 2012).

According to Elger (2011), operational performance is measured through the suits application of performance appraisal. The advantage of performance assessment reports is that an organization can be able to categorize needs for improvement. The evaluation of operational performance can be done by the line manager. The employee self- appraisal of accomplishment through which the employee fills the appraisal form before going to the operational performance interview. There is also a team appraisal which intends to recognize the team for achievement instead of appreciating the employee individually. According to Herbert (2013), operational performance is measured by the performance appraisal tool which is a process practiced by the employee and management to evaluate the operational performance of efforts in period of time which may be done quarterly or annually there is also appraisal done by customers to evaluate the external views. (Herbert, 2013)

According to Robin (2018), the balanced scorecard is an indicator or a framework for measuring the in use enactment. This instrument relies on four perceptions which are related. It measures operative performance for the institution to reach its objectives. Each strategy presents a key performance indicator (KPI) which identifies and tracked over time and indicate progress toward a desirable outcome. Tactical KPIs display the operation of institution strategies, determine gaps between actual performance and targeted performance and determine organization efficiency and operational competence. (Robin, 2018). This study summarized the conceptual framework by indicating employee turnover This diagram highlights that employee turnover is affecting the performance of commercial banks. It has been cleared that the end result of independent has a negative effect on dependent variable, where by each performance indicator has been straight linked to its related effect is presented by the projectile drawings. In fact, the calculation of employee turnover is done through the application of the formula of employee turnover rate, which provides an indication in the percentage employee who exit the institution over the given period of time. (Robin, 2018).

\section{Research Findings}

Employee compensation

\begin{tabular}{|c|c|c|}
\hline Extent & Frequency & Percent \\
\hline Highly unaccepted & 8 & 10 \\
\hline Unaccepted & 22 & 27.5 \\
\hline Neutral & 29 & 36.3 \\
\hline Accepted & 19 & 23.8 \\
\hline Highly accepted & 2 & 2.5 \\
\hline Total & 80 & 100 \\
\hline
\end{tabular}

Source: primary data, 2020.

Table 4.6 showed that $26.3 \%$ employees were happy with the compensation while $73.8 \%$ employees were not happy with the compensation provided to them at KCB Bank Rwanda. It was clear that the employees who did not accept the level of compensation might attract their intent to leave the bank. Without review of bonuses, the bank was exposed at a high risk of losing its employee at a percentage of 37.5\%. They might be either accepting or not, but given the normal employee feelings, it was clear that those $36.3 \%$ employees were not agreeing with compensation although they have avoided to react on it. This meant that KCB Bank Rwanda was exposed to high risk of losing its employee at percentage of $73.8 \%$. The findings from respondents showed that employee compensation has affected KCB Bank Rwanda at a percentage of $26.3 \%$ that caused those employees who got the most paying opportunity to exit the bank without negotiation.

Employee overscheduling

\begin{tabular}{|c|c|c|c|}
\hline \multicolumn{2}{|c|}{ Extent } & Frequency & Percent \\
\hline \multirow{4}{*}{} & Highly unaccepted & 3 & 3.8 \\
\cline { 2 - 4 } & Unaccepted & 3 & 3.8 \\
\cline { 2 - 4 } & Neutral & 34 & 42.5 \\
\cline { 2 - 4 } & Accepted & 35 & 43.8 \\
\cline { 2 - 4 } & Highly accepted & 5 & 6.3 \\
\cline { 2 - 4 } & Total & 80 & 100.0 \\
\hline
\end{tabular}

Source: Primary data, 2020.

Table 4.7 showed that $42.5 \%$ employees could not testify if they were doing the required tasks or not. It meant that they were simply adopting and accomplish tasks luckily. As KCB Bank Rwanda introduced new targets it might introduce 
new training to support their achievement otherwise it would face the decrease in its operational performance. Those $7.6 \%$ employees who unaccepted meant that to have mixed including job description and other duties that accrue due to a discretion of the bank's engagement.

Table 4.7 showed that $50.1 \%$ employees accepted to handle duties that meant that the normal overscheduling might lead to the office close once employee called in sick or in resignation. In these circumstances, only $6.3 \%$ employee could tolerate or accept to handle extra duties scheduled to them. This meant that a raising commercial bank in Rwanda might outsource and benefit from the existing employee who have had banking experience. It was clear that KCB Bank Rwanda had a hard task to recruit new employees in order to handle the issue of overscheduling upon its existing employees otherwise it would lose employee at a percentage of $91.8 \%$ which might lead to merge, closure, or liquidate. The findings from respondents showed that employee overscheduling affected KCB Bank Rwanda at a percentage of $50.1 \%$ that caused those employees to work unhappily with intention to exit the bank.

\section{Employee favouritism}

\begin{tabular}{|c|c|c|c|}
\hline \multicolumn{2}{|c|}{ Extent } & Frequency & Percent \\
\hline \multirow{4}{*}{} & Unaccepted & 5 & 6.3 \\
\cline { 2 - 4 } & Neutral & 18 & 22.5 \\
\cline { 2 - 4 } & Accepted & 41 & 51.3 \\
\cline { 2 - 4 } & Highly accepted & 16 & 20.0 \\
\cline { 2 - 4 } & Total & 80 & 100.0 \\
\hline
\end{tabular}

Source: Primary data, 2020.

Table 4.8 showed that $71.3 \%$ employee did not find problems in favouritism while $28.8 \%$ found favouritism as a barrier to performing well their duties. The $6.3 \%$ employees unaccepted to perform their duties while managers were presenting the favouritism in their units. This table showed that $43.8 \%$ employee did not need favouritism in their duties while $33.8 \%$ employees needed to be favoured in order to perform well their duties. The $22.5 \%$ employee thought that they could perform well their duties no matter how they are favoured or not. Through this table, it was clear that at a percentage of $56.3 \%$ favouritism could affect negatively the operational performance of KCB Bank Rwanda. Table 4.8 showed that $6.3 \%$ employees intended to exit the KCB Bank Rwanda due to favouritism. Through the 22.5\%, employees who were neutral were clear that the bank might lose its employee at such a percentage because of favouritism found in banking workplace. Thus, only $20.0 \%$ employees performed well in the bank's operations without considering favouritism held in their workplace. The findings from respondents showed employee favouritism had affected KCB Bank Rwanda at a percentage of $71.3 \%$, which increased the rate of turnover in bank whereas its operational performance was affected at $86.3 \% 9$ (see table 4.9).

\section{Operational performance}

Source: Primary data, 2020.

\begin{tabular}{|l|l|l|l|}
\hline \multicolumn{2}{|l|}{} & Frequency & Percent \\
\hline \multirow{2}{*}{} & Unaccepted & 1 & 1.3 \\
\cline { 2 - 4 } & Neutral & 10 & 12.5 \\
\cline { 2 - 4 } & Accepted & 41 & 51.3 \\
\cline { 2 - 4 } & Highly accepted & 28 & 35.0 \\
\cline { 2 - 4 } & Total & 80 & 100.0 \\
\hline
\end{tabular}

Table 4.9 showed that Table 4.9 showed that KCB Bank Rwanda measured the productivity of employees and customer satisfaction throughout the balanced scorecard at a percentage of $86.3 \%$. The employee's innovation failed at $1.3 \%$. Though $12.5 \%$ employee were neutral, this meant that they could not innovate $\mathrm{t}$ work. The bank measured the operational productivity of its employee yet the journey was still long since there are $13.8 \%$ employees who did not accept. It was clear that the KCB Bank Rwanda might lose its productivity at a percentage of $13.8 \%$ due to the noncompliance of productivity measurement. The findings from respondents showed that the operational performance of KCB Bank Rwanda decreased at $13.8 \%$ due to employee turnover.

\section{Conclusion And Recommendation}

The research indicated employee turnover as a major problem that has affected the operational performance of commercial banks in Rwanda. The case of KCB Bank Rwanda, and who have been considered as the key persons and talented performers of the bank, and therefore they have left with immediate effect without a room for negotiation. The 
study found out that KCB Bank Rwanda has recognized a considerable rate of staff turnover at a percentage of $46.5 \%$ during the period of January 2020 to December 2020 where the low number of staffs who were recruited low compared to the number of staffs who left the bank. Staff turnover turned to 12 staffs as the number of staffs who left were 8 staff representing $66.6 \%$ while staffs recruited were 4 representing $33.3 \%$. This was caused by factors including poor employee compensation, employee over scheduling and employee favouritism. The said percentage is one of factors that have attracted internal job rotation, roasted over scheduling, and unfair promotion subjective to the performance evaluation done by line managers through balanced scorecards (BScs). The research study has discovered that the most concern of KCB Bank Rwanda was not the relevance of number of employees who have left the bank, but rather the quality of those staff and the targets they have set during the set and submission of the annual balanced scorecard which affects the operational performance review. The rate of staff turnover has caused the over scheduling and stress to the current staff. It has affected the staff resolve to team it caused staff to whom the management had believed as high performer seemed to resign. The findings from respondents showed that employee compensation affected KCB Bank Rwanda at a percentage of $26.3 \%$ that caused those employees who got the most paying opportunity to exit the bank without negotiation. The research proved that $26.3 \%$ (see table 4.6) employees accepted the efficiency of compensation at KCB Bank Rwanda while 37.5\% (see table 4.6) employees find inefficient compensation. In fact, 36.3\% (see table 4.6) employees were neutral which meant that they were not compensated at the standard of Rwanda's local market. The research has assessed that $62.6 \%$ (see table 4.6) employees are not happy with their compensation that affects their satisfaction and increases their probability to leave the bank at $13.8 \%$ (table 4.9) in a predictable future.

The research has showed that overscheduling was a big challenge that caused employee turnover in KCB Bank Rwanda where $50.1 \%$ (see table 4.7) employee were accepting the duties assigned to them especially in department of Operations and Logistics, and department of Retails. These two departments supervised directly the operational performance of 15 branches of KCB Bank Rwanda. This meant that about 6.3\% (see table 4.6) employee were highly happy with their duties. The study assessed that at 50.1\% (see table 4.7), the bank was at a risk to lose employee due to overscheduling. The reason that employee presented their whistling to be handling duties in the absence of their coworkers, because $7.6 \%$ (see table 4.6) employees were quite sure they would leave their positions in future due to heavy tasks over-scheduled to them.

The research findings showed that employee favouritism affected KCB Bank Rwanda at a percentage of $71.3 \%$, which increased the rate of employee turnover. The research found that $28.8 \%$ (see table 4.8 ) employee proved that favouritism affected negatively their performance. The $6.3 \%$ (see table 4.8 ) employees meant to exit the bank due to favouritism. The research found out that only $71.3 \%$ (see table 4.8) employees accept the favouritism. Therefore, favouritism was a big challenge that affected the operational performance of KCB Bank Rwanda high rate of $28.8 \%$ (see table 4.8) that caused employee to lose confidence. Employee were not happy to see their workmates favoured by their managers, and affected their working truthful and increased their probability to leave the KCB Bank Rwanda at $6.3 \%$ (see table 4.8).

operational performance of KCB Bank Rwanda decreased at a percentage of $13.8 \%$ due to employee turnover. According to table 4.9, the determination of the operational performance of commercial banks in Rwanda proved an improvement in production, easiness in familiarizing to technology, and highly motivated employees. KCB Bank Rwanda measured the operational performance through employee and customer satisfaction; however, the journey was still long since there are $13.8 \%$ respondents who did not accept the operational performance measurement. This meant affected the bank with intent to lose productivity at a percentage of $13.8 \%$ due to the noncompliance of productivity measurement.

Although KCB Bank Rwanda has taken measures to fight staff turnover but the implementation has not been excised which continued to increase the number of leavers. It not compulsory that the human resource management should make a strongest approach through the heads of departments and line managers to ensure that every member of the staff is made happy in the workplace. This will raise the value of staff and the anthropological store running should consider establishing effective rewarding system which is proposed to catalyse enthusiasm, commitment, engagement and the development of staff while observing fairness, equity, consistency, and transparency in operational performance. The payment system should be designed by in view of the nature of programmed works and the level of schooling, and work experience because these characteristics affect the staff safeties and satisfaction which attract the incomings plans. The research endorsed that fast solutions should be done in a manner of stimulating staff to the positions they were actual to be in. the managing should involve employees in the pronouncement making process, must set a staff assistance programme to eliminate absenteeism bias in the workplace. The study recommends that the super vision should reduce work tediousness to staff by revisiting their job descriptions and visiting their office desks in order to discover added and non-corresponding tasks that may attract them to leave the bank.

\section{References}

[1].Adnan (2017), Employee Turnover: Causes, Consequences and Retention Strategies in the Saudi Organizations.

[2].Prince Sultan University. P-8, 12.

[3].Albert (2010), Microfinance Growth Challenges, Journal of Economics (Vol. 6). P-21, 23.

[4].Ali (2010), Employees Turnover and organization efficiency, Journal of Human Resource Management, (Vol.

[5].19), $P-32,33$.

[6].Armstrong (2012), Handbook of Human Resource Management Practice. 12th ed. London, Kogan Page Publishers. P-572, 854, 913.

[7].Carole (2018), Employee favoritism in the workplace. Michigan: Michigan State University. P-72 
[8].Catherine (2020). KCB Bank Rwanda Employee Turnover Report. Kigali, Department of Human Resource Management. P-44, 45.

[9].Colvin (2011), An employment systems approach to turnover: human resources practices, quits, dismissals, and performance, Academy of Management Journal (Vol. 54). P-26, 37, 38.

[10]. Dau-Schmidt (2014), The Definition of "Employee” in American Labor. Bloomington: Indiana University. P-340, $341,342$.

[11]. Duarte (2015), Operational Practices and Financial Performance, Journal of Management (Vol.6). p-17, $18,19$.

[12]. Easton (2018), Young Women's Trust. Canada: Young Women's Trust. P-27, 28.

[13]. Eduard (2010), Cost of Employees Turnover, Journal of Human Resources Management (Vol. 22). P-32, $33,34$. Edward (2010), Cost of Employees Turnover, Journal of Management(Vol. 22) . P-21, 22, 23.

[14]. Edgard (2014), Employment and Jobs Study. University of Southern Calfonia. P-249, 250, 257. Elger. (2011), Performance theory and organizational development, London: MacMillan. P-375 Frederick (2010), Employees' Turnover Repercussions, Journal of management, (Vol. 6). P-29, 30.

[15]. Guest (1987), Operational Performance, Jounal of Management, (Vol. 7), London. P-49, 50. Herbert (2013), Split Roles in Performance Appraisal, Harvad Business Review, P-123.

[16]. Hong. (2010), Problems of employee favoritism. Jiangsu: Jiangsu University. P-314, 315, 316, 317. Immaculee. (2014). Rwanda Financial Stability Survey. Kigali: Access to Finance Rwanda. P-37, 38.

[17]. John. (2019), Financial Stability Report. Kigali: National Bank of Rwanda. P-70, 71.

[18]. Luciana (2015), Employee Turnover and Organizational Performance: a Study of the Brazilian Retail Sector, Vitória-ES: Brazilian Business Review, (Vol. 12). P-44, 45.

[19]. Magalla. (2011). Factors influencing employee turover in Tanzania organization. Dodoma: University of Dodoma. P-78, 79, 80.

[20]. Mahoney (2012), The Over-Scheduling Hypothesis Revisited. US Library of Medecine. P-214, 215.

[21]. Maxwell (2010), Employees' Turnover and organization efficiency. Journal of Personnel Management. P-47, 48. Michel (2019), KCB Bank Rwanda's Reporting Benchmark. Kigali: KCB Risk and Compliance Department. P-

[22]. 44, 47.

[23]. MINECOFIN (2018), Economic Development and Poverty Reduction Strategy, Phase II. Kigali: Ministry of Finance and Economic Planning (MINECOFIN). P-88, 92.

[24]. Mrope (2014), Assessment of employee turnover on organizational efficiency, Journal of Human Resource Management (Vol. 3). P-52, 53.

[25]. Nassazi (2013), Effects of training on employee performance. Vaasan ammattikorkeakoulu university of applied sciences. P-370, 377.

[26]. Nemli (2010), Impact of Strategic Human Resource Management on Organizational Performance, Journal of Naval Science and Engeneering, (Vol. 6). P-47.

[27]. Ng'ethe (2012), Influence of leadership on employee turnover. Nirobi: Fountain Publishers. P-72.

[28]. NISR (2017), Rwanda Labour Statistics Framework, Kigali: National Institute of Statistics. P-84 NST (2017, National Strategy for Transformation, Kigali: Government of Rwanda. P-27.

[29]. Nuray (2016), Effect of Compensation on Job Performance, International Journal of Engineering Technology, Management and Applied Sciences. P-104, 106.

[30]. Nwokocha (2012), Effect of employee turnover in globalizing the economy. Lagos: Nigeria Publishers. P-82, 88. Ongori (2010), Employee turnover in Botswana organizations. Gaborone: Fountain Publishers. P-39, 44.

[31]. Poverty Global Practice Africa Region (2015), Rwanda Employment and Jobs Study. Kigali: World Bank Group.

[32]. P-55, 58.

[33]. Robin (2018), Rwanda Banking and Investment Analysis, Fueling Enterprise Innovation, Growth and Job Creation. Kigali: USAID. P-73, 75.

[34]. Ruchika (2015), How does gender diversity improve firm performance in India. Mumbai: International labour organisation. P-63, 69.

[35]. Redmond (2010), Employee compensation and motivation. Birmingham: University of Birmingham. P-73, 74. Suzan (2011), Rwanda Financial System Stability Assessment, International Monetary Fund. P-27.

[36]. Shamsuzzoha (2010), Effects of employee turnover on financial stability. Bostwana: Botswana University of Science and Technology. P-93, 104.

[37]. Silas, (2015), An assessment of the role of commercial banks in promoting trade in rural areas. Kigali: National University of Rwanda. P-77, 79.

[38]. Shukla (2013), Effects of employee turnover in Kenya Banking industry. University of Nairobi. P-45

[39]. Thomas (2020), Balanced Scorecard. Retrieved from BSC Automation and Performance Analysis: https://balancedscorecard.org/bsc-basics-overview/ accessed on 23th May, 2020.

[40]. Vroon (2013), Effect of employees' work experience on performance. Cairo: University of Cairo. P-277, 278 Wanderi (2012), Assessment of causes of labour turnover in three and five star-rated hotels inKenya. Nairobi:

[41]. International journal of business and social science. P-43

[42]. William (2009), The Labor Relations Process (9 ed.), Mason, Library of Congress. P-573, 575.

[43].Woodall (2005), Employee performance appraisal and organization performance. London: Fountain Publishers. P-272, 273. 